\title{
In silico Antiurolithiatic Screening of Aerva lanata (L) Isolated constituents
}

\author{
Basavaraj M Dinnimath ${ }^{1}$ and Sunil S Jalalpure ${ }^{\star 2}$ \\ 'Department of pharmachemistry, KLEU's college of pharmacy Belgaum-590010, Karnataka-India \\ ${ }^{2}$ Department of pharmacognosy, KLEU's college of pharmacy Belgaum-590010, Karnataka-India
}

\begin{abstract}
Background: Traditionally known as Pashanabheda in India, Aerva lanata (L) belonging to the family Amaranthaceae, is widely available in Western ghats of India and used as Antiurolithiatic, astringent, diuretic, antimicrobial, antiinflammatory, hepatoprotective drug by Indian traditional system of medicines. Materials and Method: In the present study this herb is subjected to extraction with hydro alcohol followed by fractionation with different solvents of varying polarities such as dichloromethane, ethyl acetate and n-butanol and screened for Antiurolithiatic activity using ethylene glycol induced male Wistar albino rats. Based on the results, the potent fractions were subjected to isolation of active constituents using column chromatography. Results: The isolated compounds from two fractions n-butanol and ethyl acetate were characterized by modern analytical techniques such as IR, HPTLC, NMR and LCMS as Quercetin and Betulin. Later these two compounds were studied for Antiurolithiatic activity by In silico technique by docking with a protein 2 ETE of Oxalate oxidase from PDB and the results indicated better regio-specificity with the enzyme. Conclusion: The two compounds isolated from potent fractions based on bioactivity guided fractionation were characterized as Quercetin and Betulin by modern analytical techniques. These two compounds were studied by in silico method and these two compounds have produced significant results which substantiate their claim of bioactivity. However in vivo study is needed to confirm the activity.

Key words: Aerva lanata (L), Pashanabheda, isolation and characterization, Antiurolithiatic agents, In silico study.
\end{abstract}

\section{INTRODUCTION}

Pashanabheda (stone dissolving) plants are a group of medicinal plants which are used in Indian traditional medicinal system by Ayurvedic practitioners as Antiurolithiatic drugs. Traditionally Aerva lanata (Pashanabbeda) is used as both Antiurolithiatic and diuretic.

The traditional medicines system is a rich source of valuable medicinal plants but there is no scientific data to establish the activity of these plants. These plants need to be evaluated, based on their biological efficacy and chemical constituents for the drug development. Hence we have selected Aerva lanata (L) which is traditionally used as Pashanabheda plant (stone dissolving) for Urolithiasis, available from Western Ghats region for our present study. Bioactivity guided fractionation of this plant was car- ried out in order to investigate the traditional claim.

Many of the medicinal plants available in India have not been studied scientifically for their activity till date. Also there is no spectral data available regarding the active constituents present in these plants which are responsible for their efficacy. Hence there is a need to identify active constituents of these plants and screen them for their various activities to support their traditional claims. In this present study, Aerva lanata Linn. (Amaranthaceae) a herbaceous perennial weed which is available in the tropical regions and Western Ghats of India is selected. The herb Aerva lanata commonly known as Pashanabbeda has been claimed to be useful for its diuretic, anthelmintic, anti diabetic, expectorant, hepatoprotective,
Submission Date: $11 / 06 / 2014$ Revision Date : :10/09/2014 AcceptedDate : $: 23 / 12 / 2014$

DOI: $x x x$

Correspondence Address

Dr. S S Jalalpure,

Professor,

Dept of Pharmacognosy,

KLEU'S College of Pharmacy, Belgaum-590010,

Karnataka India.

mobile:919448964057

Email address:jalal-

puresunil@rediffmail.com

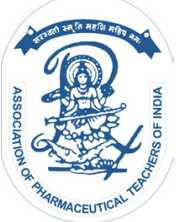

www.ijper.org 
antimicrobial, cytotoxic activity, antiurolithiatic and anti-inflammatory activity. ${ }^{1,2}$

This plant is commonly used in Ayurvedic medicines and recommended in Ayurvedic texts for various diseases. It is useful to treat boils, cephalalgia, cough and urolithiasis. The plant extract is proved for nephroprotective activity, diuretic effect, cytotoxicity and antioxidant, immunomodulatory effect, diuretic effect, anti-inflammatory effect, antimicrobial activity, hepatoprotective activity, anti hyperglycemic effect. ${ }^{3,4}$

Although this plant is used traditionally by Ayurvedic physicians, however, there is no report on the spectral analysis of different fractions of Aerva lanata (L) till date. Also there is no report on the active constituents responsible for the biological activities claimed by the plant. Hence this plant available in Western Ghats of Khanapur region is selected for the study.

\section{MATERIALS AND METHODS}

\section{Materials and Reagents}

The whole plant Aerva lanata $(\mathrm{L})$ is procured from Western Ghats region of Khanapur Taluka, Belgaum for the study. It's a herb widely available in this region. The plant is authenticated by taxonomist Dr. Harsha Hedge, Scientist B, RMRC, Belgaum (specification noRMRC-507). The whole plant is subjected to shade drying and then it was ground to coarse powder. The powdered dry material was used for the extraction with hydro alcohol. Aqueous extract was prepared by dissolving the dried hydro alcoholic extract in distilled water and the aqueous extract was partitioned with different solvents of varying polarities [dichloromethane ethyl acetate and n-butanol (S.D Fine chem. Ltd.)] in a separating funnel. The organic fractions were purified by washing with distilled water and treated with sodium sulphite overnight to remove moisture. These fractions were subjected to qualitative tests and chromatographic techniques. ${ }^{3}$

\section{Animals}

Male Wistar albino rats weighing 150-200 g were purchased from Sri Venkateshwara traders, Bangalore. They were housed in acryl fiber cages at $23 \pm 2^{\circ} \mathrm{C}$, humidity $50 \pm 1 \%$ and were kept on a $12 \mathrm{~h}$ light/dark cycle. They were fed with standard chow feed (Amrut laboratories, Sangali) and water ad libitum and acclimatized for 15 days before the study. Experimental protocols reported in this study were approved by the Institution Animal Ethical Committee of CPCSEA, Govt. of India (IAEC-Resolution No-13, 31-07-2010) and carried out in accordance with OECD guidelines.

\section{Acute toxicity assay}

Acute toxicity assay was performed as per OECD guidelines 423 (limit test). Six male Wistar albino rats (three animals in each step) were randomly selected. The animals were kept fasting for overnight providing only water. The extract was administered orally at one dose level of $2000 \mathrm{mg} / \mathrm{kg}$ b.wof the animals. In further rats were observed continuously for the first $4 \mathrm{~h}$ and then periodically up to $24 \mathrm{~h}$ for toxic symptoms and mortality. The number of deaths was noted to calculate $\mathrm{LD}_{50}$ and therapeutic dose.

\section{Isolation}

These fractions (II and III) were subjected to screening for Antiurolithiatic activity using ethylene glycol $(0.75 \%)$ (S.D. Fine. Chem. Ltd) induced Albino wistar male rats for 24 day study. The animals were divided into seven groups containing six each. The group I served as control and fed with normal rat food and water ad libitum. Group II to VII received ethylene glycol $(0.75 \%)$ orally in drinking water from day 1 to day 28 for the induction of renal calculi. Group II served as disease induced group. Group III received standard drug Cystone (750 $\mathrm{mg} / \mathrm{kg}$ b.w) from 14 th day to 28 th day. Group IV received fraction II $(20 \mathrm{mg} / \mathrm{kg}$ b.w.) group $\mathrm{V}$ received fraction II (40 mg/ $\mathrm{kg} \mathrm{b.w})$, group VI received fraction III $(20 \mathrm{mg} / \mathrm{kg}$ b.w.) and group VII received fraction III (40 mg/kg b.w) from 14th day to 28 th day. 4,5

The Phytochemical screening of the extract and fractions II and III showed mainly the presence of flavanoids, Saponins, Triterpenoids, glycosides, steroids and phenolic compounds. (Figure 1)

No crystal deposition was found in normal group animals. Kidney section of rats treated with ethylene glycol $(0.75 \%)$ showed deposition of micro crystals. There was tubular damage, infiltration of inflammatory cells into the interstitial space. Kidney section of animals treated with extract and fractions showed improvement of the above symptoms and reduced crystal deposition.

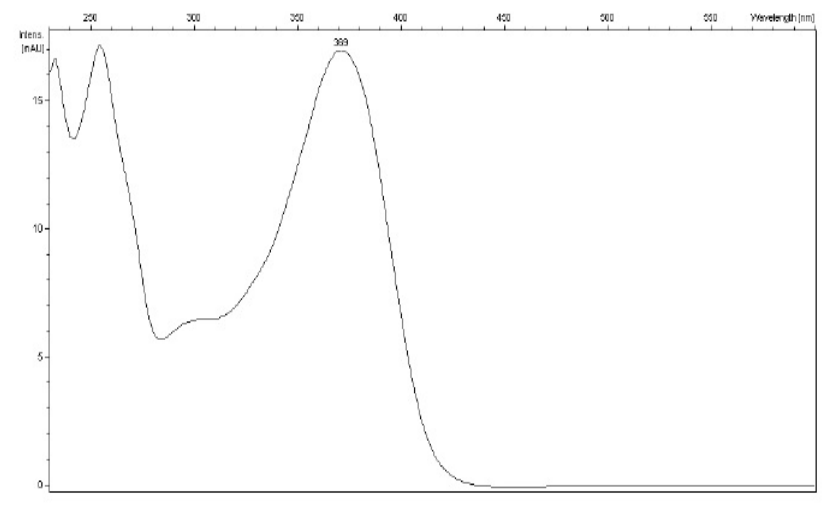

Figure 1: UV spectrum of AEF 1 


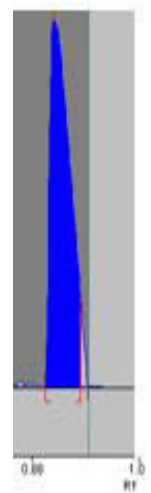

Figure 2: Qualitative analysis of AEF 1 by HPTLC

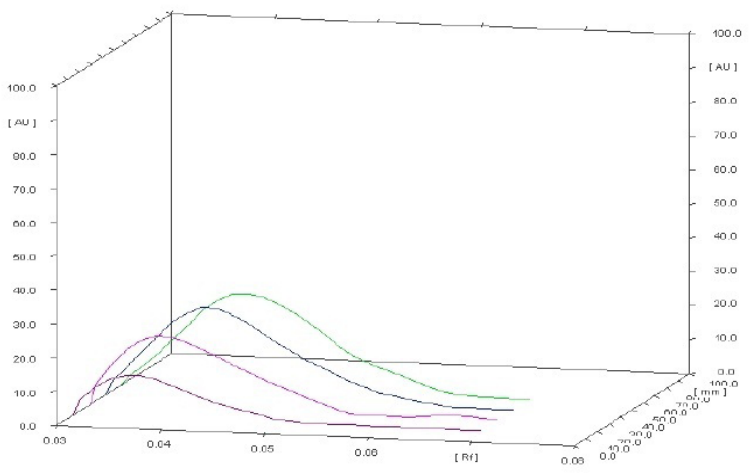

Figure 3: Comparison of HPTLC spectrum of AEF 1 on different tracks

Based on the biochemical and Histopathological results, these fractions were subjected to isolation of potent compounds by using column chromatography technique followed by preparative TLC. The isolation technique has successfully isolated two compounds. These isolated compounds were subjected to characterization process by modern analytical techniques such as IR, HPTLC, ${ }^{1} \mathrm{HNMR},{ }^{13} \mathrm{CNMR}$ and LCMS.

The column $(3.5 \times 60 \mathrm{~cm})$ was prepared with silica gel (60-120 mesh) in chloroform by wet method and column is put for overnight. Then the n-butanol fraction (5 gm) was poured to silica gel open column chromatography and step gradient technique was used to run the column. Various ratios of Methanol-chloroform (1:10, 500 $\mathrm{ml} ; 1: 5,500 \mathrm{ml} ; 1: 3,500 \mathrm{ml} ; 1: 2,350 \mathrm{ml})$ were used for the isolation of active component. The 20 fractions of $20 \mathrm{ml}$ each were collected; analyzed by TLC and same type of fractions were mixed; then again analyzed by TLC and found that the aimed compound is present as a single spot in the fraction collected from the 1:2 solvent system and the Rf value determined .

Similar method was used to isolate active compound/s from ethyl acetate fraction. Then the ethyl acetate fraction (5 gm) was poured to silica gel open column and Various ratios of Methanol-chloroform $(1: 10,500 \mathrm{ml}$; $1: 5,500 \mathrm{ml} ; 1: 3,500 \mathrm{ml} ; 1: 2,350 \mathrm{ml}$ ) were used for the

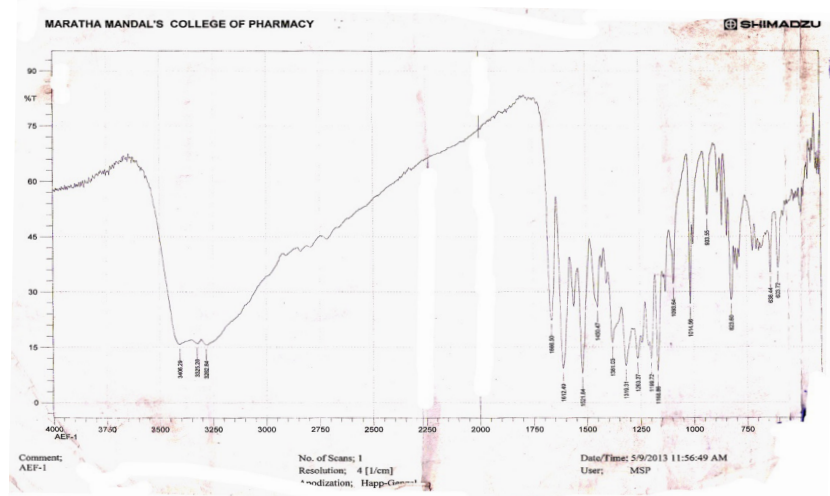

Figure 4: I.R spectral analysis of AEF 1

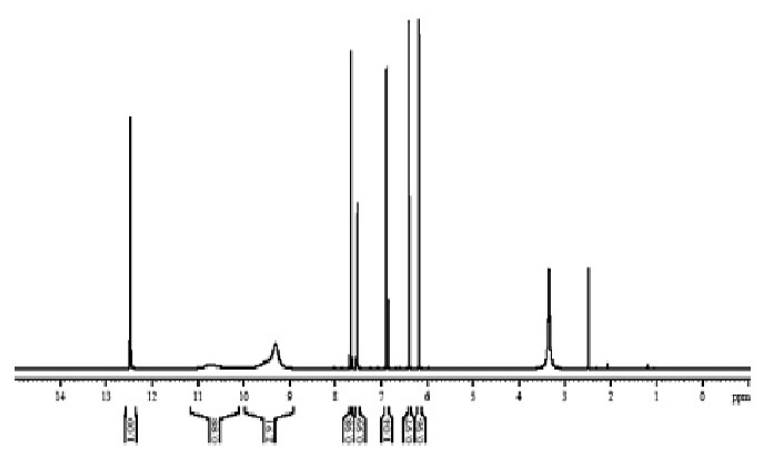

Figure 5: ${ }^{1} \mathrm{H}$ NMR spectra of AEF-1

isolation of active component (2). The fractions of 20 $\mathrm{ml}$ were collected; analyzed by TLC and same type of fractions are mixed; then again analyzed by TLC and found that the aimed compound is present as a single spot in the fraction collected from the 1:2 solvent system and the Rf value determined. But in this step a complex spot was observed in the TLC of the combined fractions of ethyl acetate. Later the complex spot was resolved into two spots with almost close $\mathrm{Rf}$ values 0.53 and 0.56. After isolation these three compounds were subjected to characterization by IR, HPTLC, NMR and LCMS. (Table 1-3)

\section{Instrumentation}

The TLC spots were analyzed by Iodine chamber, the standard drugs Quercetin and Betulin used for comparison and Rf values were determined. After TLC analysis, the compounds were studied by CAMAG HPTLC instrument for their qualitative analysis. Then the compounds were subjected to SHIMADZU FT-IR Spectrophotometer for identifying the probable functional groups present. After IR spectral analysis, the compounds were studied for ${ }^{1} \mathrm{HNMR}$ using 400 $\mathrm{MHz}$ BRUKER FT-NMR and ${ }^{13} \mathrm{CNMR}$ by $100 \mathrm{MHz}$ BRUKER FT-NMR Spectrophotometer for studying the Proton NMR and Carbon NMR spectra. Thermo 
Table 1: I.R spectral data of isolated compounds

\begin{tabular}{|l|l|}
\hline \multicolumn{1}{|c|}{ Compound } & \multicolumn{1}{|c|}{ Vibrations in $\mathbf{c m}^{-1}$} \\
\hline AEF 1 & $\begin{array}{l}\text { 3406(O-H), 1582 }(\mathrm{C}=\mathrm{C}), 1665 \\
(\mathrm{C}=\mathrm{O})\end{array}$ \\
\hline AEF 2.3 & $\begin{array}{l}3414(\mathrm{O}-\mathrm{H}), 2943(\mathrm{Ar}-\mathrm{H}), \\
1643(\mathrm{C}=\mathrm{O})\end{array}$ \\
\hline
\end{tabular}

Table 2: NMR Spectral data of isolated compounds

\begin{tabular}{|c|c|c|}
\hline Compound & Proton & Carbon \\
\hline AEF 1 & $6.38,6.39,6.88$. & $93.31,98.15$, \\
& $7.68,9.37,10.7$, & $102.98,115.04$, \\
& 12.47 & $115.57,119.94$, \\
& & 121.94 \\
\hline AEF 2.3 & $1.1,1.3,1.4,1.7$, & $40,53,55,60,71$, \\
& $2.1 .2 .3,2.46,3.0$ & 106,122 \\
& $3.2,3.8,4.6$, & \\
& $4.68,4.75$ & \\
\hline
\end{tabular}

Table 3: LCMS Spectral data of isolated compounds

\begin{tabular}{|c|c|c|}
\hline Compound & $\begin{array}{c}\text { Molecular ion( } \\
\mathbf{m} / \mathbf{z})\end{array}$ & Molecular formula \\
\hline AEF1 & $302(\mathrm{~m}+1)$ & $\mathrm{C}_{15} \mathrm{H}_{10} \mathrm{O}_{5}$ \\
\hline AEF2.3 & $443(\mathrm{~m}-1)$ & $\mathrm{C}_{30} \mathrm{H}_{50} \mathrm{O}_{2}$ \\
\hline
\end{tabular}

\begin{tabular}{|c|c|c|c|c|}
\multicolumn{5}{|c|}{ Table 4: Molecular docking simulation results with 2} \\
ETE \\
\hline Compound & $\begin{array}{c}\text { Binding } \\
\text { energy } \\
\text { kcal/mole }\end{array}$ & $\begin{array}{c}\text { Docking } \\
\text { energy } \\
\text { kcal/mole }\end{array}$ & $\begin{array}{c}\text { No of } \\
\text { binding } \\
\text { sites }\end{array}$ & $\begin{array}{c}\text { total no } \\
\text { H }\end{array}$ \\
\hline AEF 1 & -3.92 & -4.37 & 2 & 6 \\
\hline AEF 2.3 & -3.72 & -4.11 & 2 & 6 \\
\hline
\end{tabular}

analysis of the isolated compounds was carried out by DSC (Shimadzu). Finally the compounds were analyzed by LCMS SHIMADZU Spectrophotometer for determining their molecular weights and molecular formulae. However the entire compiled information was used for characterizing the compounds. ${ }^{9-11}$

\section{Molecular docking studies:}

Isolated compounds AEF 1 (Quercetin) and AEF 2.3 (Betulin) were studied by in silico technique using automated docking software (v Life, Pune). A protein 2 ETE of Oxalate oxidase was downloaded from pdb (www.rcsb. org/pdb) which reportedly participate in kidney stone formation.

\section{RESULTS}

Characterization of Isolated Compounds compound 1: AEF 1

\section{Physical Properties}

The Color of the isolated compound - 1 was Yellowish; its physical state was solid, soluble in Methanol, Chloroform and DMSO. The Melting Point was found to be $315-317^{\circ} \mathrm{C}$ as determined by open capillary method and the Rf value was 0.47 as determined by TLC method.

\section{Spectral Data}

The IR spectral data $\left(\mathrm{cm}^{-1}\right)$ of isolated compound AEF 1 (KBR pellets technique) has revealed the vibrations at $3406(\mathrm{O}-\mathrm{H}), 1582(\mathrm{C}=\mathrm{C}), \mathrm{C}=\mathrm{O}$ (1665). (Table 1)

The ${ }^{1} \mathrm{HNMR} \delta$ (DMSO) spectral data has revealed the proton signals at $6.38(1 \mathrm{H}, \mathrm{d}, \mathrm{J}=1.7 \mathrm{~Hz}), 6.39(1 \mathrm{H}$, $\mathrm{d}, \mathrm{J}=1.7 \mathrm{~Hz})$. Signals at $\delta=6.88(\mathrm{Ar} 1 \mathrm{H} \mathrm{d}, \mathrm{J}=6.4 \mathrm{~Hz})$, $7.68(2 \mathrm{H} \mathrm{d}, 2.5 \mathrm{~Hz}) 9.37(1 \mathrm{H}-\mathrm{OH} \mathrm{d}, 2.2 \mathrm{~Hz}), 10.7(1 \mathrm{H} \mathrm{d}$, $2 \mathrm{~Hz}) 12.47(1 \mathrm{H} \mathrm{d}, 2 \mathrm{~Hz})$. The ${ }^{1} \mathrm{HNMR}$ spectrum showed characteristic protons at aromatic regions from 6-8 $\mathrm{ppm}$ and strong hydrogen bonding at $12.5 \mathrm{ppm}$. (Figure 5) These suggest the possibility of Quercetin nucleus in the compound. The ${ }^{13} \mathrm{C}-\mathrm{NMR}$ spectra revealed 15 carbon signals typical of flavonoid nucleus (Quercetin nucleus). (Table 2, Figure 6)

The Thermo Analytical data was determined using DSC-60 (Shimadzu) for the compound and it has shown characteristic peaks at $315^{\circ} \mathrm{C}(\mathrm{Tm})$ (Figure 8).

LCMS has revealed $\mathrm{m} / \mathrm{z}[\mathrm{M}-\mathrm{H}]^{+}$at 302 and other fragment ions at 257(15), 228 (8), 201(8), 154(8), 136(9), 110(9), 70 (4) and 23 (3). (Table 3, Figure 7)

The molecular formula was derived from the above LCMS data and it is $\mathrm{C}_{15} \mathrm{H}_{10} \mathrm{O}_{5}$

From the above analyses, the compound AEF 1 was identified as 2-(3,4 - dihydroxy phenyl) -3,5,7-trihydroxy-4H-chromen-4-one (Quercetin). The structure of the compound is<smiles>O=c1c(O)c(-c2ccc(O)c(O)c2)oc2cc(O)cc(O)c12</smiles>

Characterization of Isolated Compound 2: AEF 2.3

\section{Physical Properties}

The color of the isolated compound AEF 2.3 was Buff White, its physical state was solid, found to be soluble in Methanol and DMSO. The Melting Point was found to be $242-244^{\circ} \mathrm{C}$ (determined by open capillary method). The Rf value was 0.53 as determined by TLC method.

\section{Spectral Data}

The IR spectral data $\left(\mathrm{cm}^{-1}\right)$ of isolated compound AEF 2.3 (KBR pellet technique) has revealed the vibrations O-H (3414), Ar-H (2943), C=O (1643). (Table 1, Figure 4) 
The ${ }^{1} \mathrm{HNMR} \delta$ (DMSO) spectral data has revealed the proton signals at: $\delta$ value $1.0-1.2(\mathrm{t}, 6 \mathrm{H}) ; 1.5-1.7$ $(\mathrm{m}, 15 \mathrm{H}) ; 2.1(\mathrm{~m}, 2 \mathrm{H}) ; 2.91-3.0(\mathrm{~m}, 2 \mathrm{H}) ; 3.0-3.3(\mathrm{~d}$, $7 \mathrm{H}) ; 3.75$ (d, 7H); 3.9-4 (d, 6H); 4.3 (s, 2H);4.5 (d, 3H) and it shows the presence of 50 hydrogens in the compound. The $C^{13}$ NMR Spectrum has shown the carbon peaks at 40, 53, 55, 60, 71, 106, and 122. (Table 2, Figure 10).

Thermo Analytical study was carried out using DSC-60 (Shimadzu) and it has shown characteristic sharp peak at $240^{\circ} \mathrm{C}(\mathrm{Tm}) \cdot{ }^{15}$ (Figure 14 )

The LCMS has revealed $[\mathrm{M}+\mathrm{H}]^{+}$at 443 and other fragment ions at 413, 384, 246, 221, 193, 174 (Table 3, Figure 13).

The molecular formula was deduced for the compound AEF 2.3 based on LCMS spectra and it is $-\mathrm{C}_{30} \mathrm{H}_{50} \mathrm{O}_{2}$

From the above analyses, the compound was identified as Lup-20(29)-ene-3 $\beta$, 28-diol (Lupeol). The structure of the compound is ${ }^{11,12}$

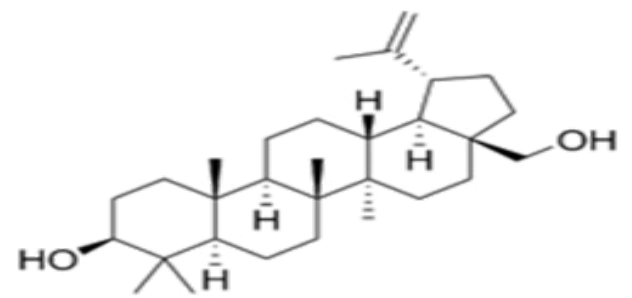

Molecular docking results of AEF 1 and AEF 2.3 using 2 ETE of Oxalate oxidase ${ }^{16,}$

Compound 1: AEF 1 (Quercetin) and AEF 2.3 (Betulin) were subjected to in silico docking studies using Autodocking software and the enzyme 2 ETE of Oxalate oxidase from pdb (www.rcsb.org/pdb). The docking results has shown that the binding strength of AEF 1 (Quercetin) in the active site of the enzyme was -3.92 $\mathrm{kcal} / \mathrm{mol}$, Docking energy $-4.37 \mathrm{kcal} / \mathrm{mol}$ and six $\mathrm{H}$-bonds were predicted between Quercetin and the enzyme. This indicates that Quercetin can act as a better inhibitor of the enzyme. (Table 4, Figure 9)

Docking results of Compound 2: AEF 2.3 ( Betulin ): The docking results has shown that the binding strength of AEF 2.3 (Betulin) in the active site of the enzyme was $-3.72 \mathrm{kcal} / \mathrm{mol}$, Docking energy $-4.11 \mathrm{kcal} / \mathrm{mol}$ and six H-bonds were predicted between Betulin and the enzyme. This indicates that Betulin can also be a better inhibitor of the enzyme. (Table 4, Figure 15)

\section{DISCUSSION}

The herb Aerva lanata (L) was collected from Western Ghats of Belgaum region (India) and subjected to extraction with hydro alcohol. The crude extract was dried and fractionated with different solvents of vary- ing polarities such as Dichloromethane, ethylacetate and n-butanol with an objective of isolating group of active constituents. Based on the preliminary phytochemical investigations and spectral analysis, these two fractions (ethyl acetate and n-butanol) were later subjected to bioactivity guided isolation of potent active constituents using column chromatography followed by preparative TLC. Ethyl acetate and n-butanol have yielded two compounds, one from n-butanol (AEF 1) and two from ethyl acetate with almost closer Rf values. These isolated compounds were characterized by using modern analytical techniques such I.R, HPTLC, ${ }^{1}$ HNMR, ${ }^{13}$ CNMR and LCMS.

The compound isolated from n-butanol (AEF 1) was characterized as Quercetin and the compounds isolated from ethyl acetate (AEF 2.3) was characterized as Betulin. Compound 1 (AEF 1) was isolated as a yellow powder. The I.R spectrum of the compound has shown characteristic peaks for the presence of functional groups $3406(\mathrm{O}-\mathrm{H}), 1582(\mathrm{C}=\mathrm{C}), \mathrm{C}=\mathrm{O}$ (1665) which were characteristic of flavanoids. The qualitative analysis of the compound by HPTLC has shown Rf value at 0.5 and the peak height was 40 . The isolated compound AEF 1 was analyzed by DSC-60 Shimadzu for thermo analytical information and it has shown characteristic endothermic peak at $315^{\circ} \mathrm{C}$ (Melting, Temp $T_{n}$ ) which almost corresponds to the temp at which it melts completely. DSC analysis has shown sharp peaks which also provide information regarding purity of the sample. The ESI-MS of the compound gave a molecular ion peak $[\mathrm{M}-\mathrm{H}]$ at $m=z 302$, compatible with the molecular formula $\mathrm{C}_{15} \mathrm{H}_{10} \mathrm{O}_{7}$. Its $\mathrm{UV}$ absorptions in $\mathrm{MeOH}$ were consistent with the presence of pentahydroxyflavone structure. In the ${ }^{1} \mathrm{H}-\mathrm{NMR}$ spectrum, the aromatic region exhibited an $\mathrm{ABX}$ system at $7.73(1 \mathrm{H}, d, J=2.0$ $\mathrm{Hz}, \mathrm{H}-20), 7.62(1 \mathrm{H}, d d, J=2.0$ and $7.5 \mathrm{~Hz}, \mathrm{H}-60)$, and $6.87(1 \mathrm{H}, d, J=8.0 \mathrm{~Hz}, \mathrm{H}-50)$ due to di-substitution of ring $\mathrm{B}$ and a typical meta-coupled pattern for H-6 and $\mathrm{H}-8$ protons $\left(6.17\right.$ and $6.37, d, J=2.0 \mathrm{~Hz}$ ). The ${ }^{13} \mathrm{CNMR}$ spectrum showed the presence of 15 aromatic carbon signals.

From the ethyl acetate fraction complex spot was obtained which has yielded two compounds with almost close $\mathrm{Rf}$ values. However it was later resolved into one compound Compound-2 (AEF 2.3). It was isolated as white powder ( $\operatorname{Rf} 0.53)$. The thermo analytical data of AEF 2.3 as determined by DSC-60 Shimadzu has shown characteristic endothermic peaks at $215-220^{\circ} \mathrm{C}\left(T_{m}\right)$. The I.R spectrum of the compound has shown the presence of functional groups such as $\mathrm{O}-\mathrm{H}\left(3414 \mathrm{~cm}^{-1}\right), \mathrm{Ar}-\mathrm{H}$ $\left(2943 \mathrm{~cm}^{-1}\right), \mathrm{C}=\mathrm{O}\left(1643 \mathrm{~cm}^{-1}\right)$ which are characteristic of Triterpenoids. The ESI-MS of the compound gave a molecular ion peak $[\mathrm{M}-\mathrm{H}]$ at $m=₹ .443$ correspond- 


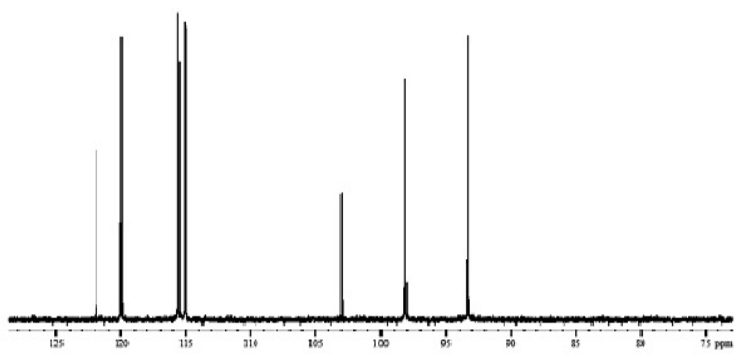

Figure 6: ${ }^{13} \mathrm{C}$ NMR spectra of AEF-1

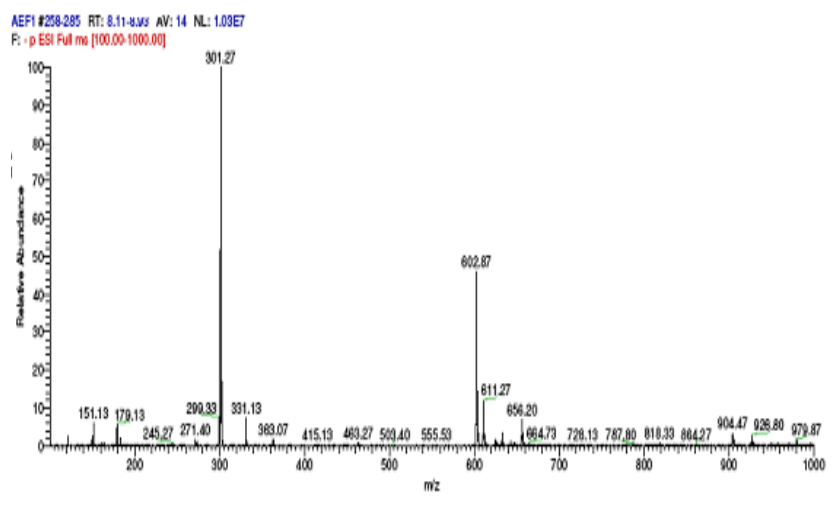

Figure 7: LC - MS spectrum of AEF 1

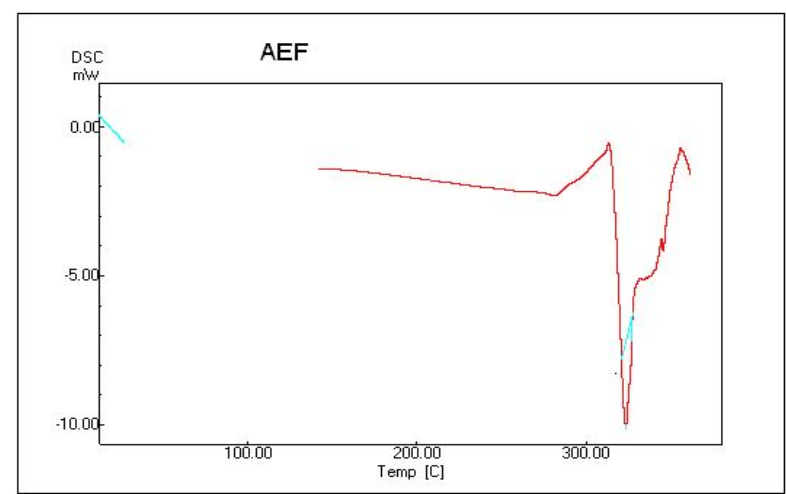

Figure 8: Thermo Analytical data of AEF 1 by DSC

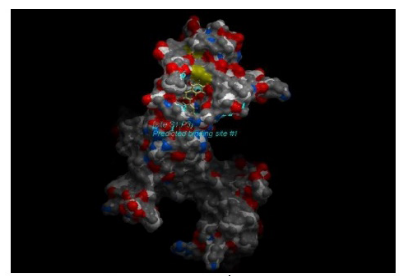

a)

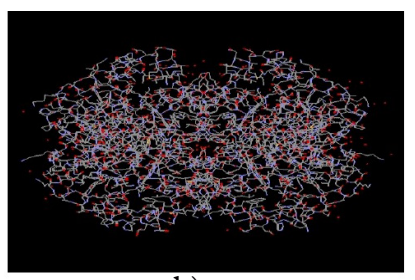

b)

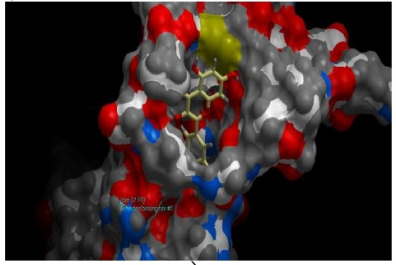

c)

Figure 9: a) Predicted binding site of 2 ETE b) 2 ETE from PDB (energy minimized) C) Docking of the molecule (AEF 1)

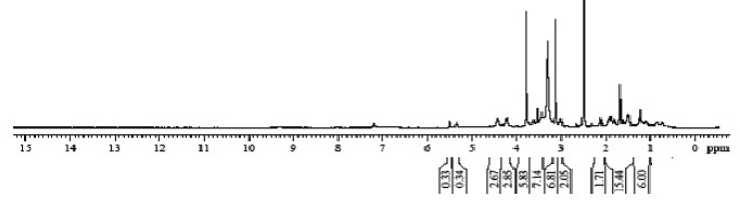

Figure 10: ${ }^{1} \mathrm{H}$ NMR Spectrum of AEF 2.3 AEF

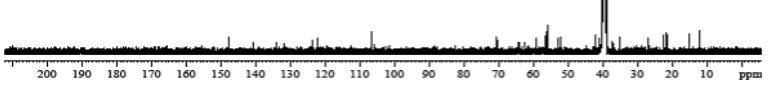

Figure 11: ${ }^{13} \mathrm{C}$ NMR Spectrum of AEF 2.3

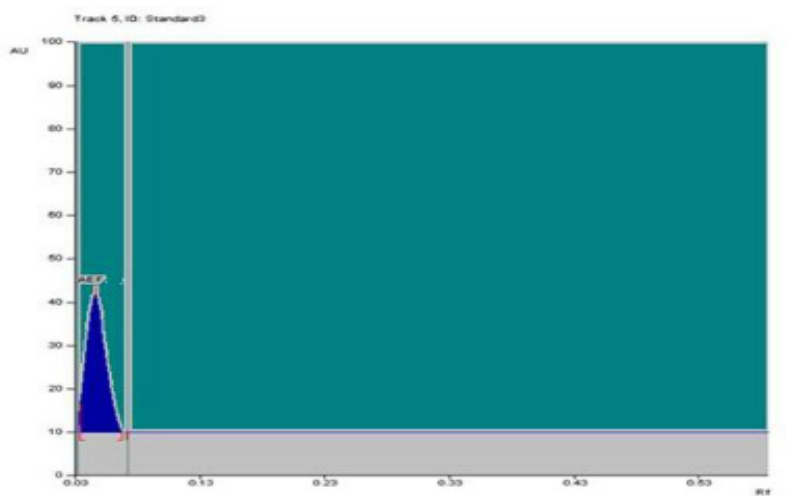

Figure 12 : HPTLC Spectra of AEF 2.3
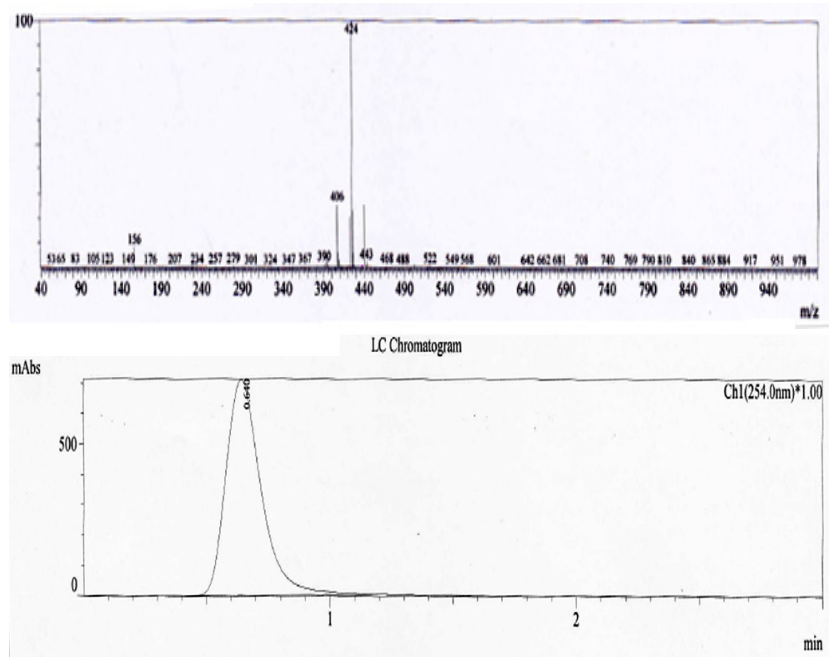

Figure 13: LCMS spectrum of AEF 2.3 


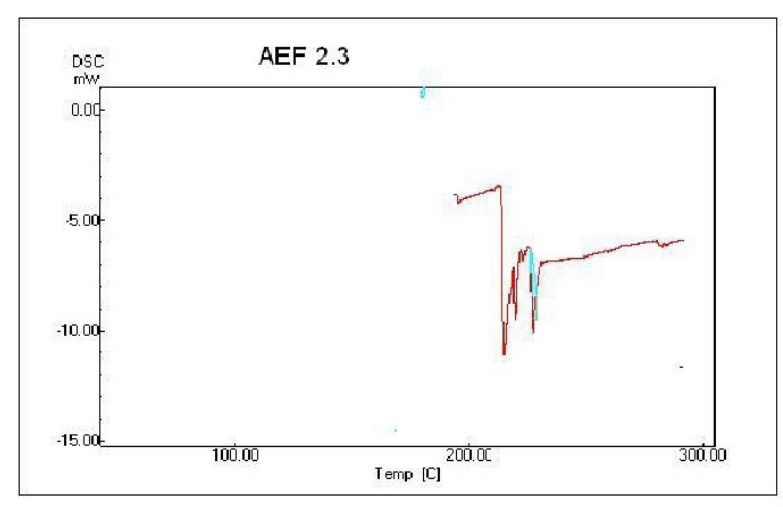

Figure 14: Thermo analytical study by DSC

ing with the molecular formula $\mathrm{C}_{30} \mathrm{H}_{50} \mathrm{O}_{2}$. The ${ }^{1} \mathrm{H}$ NMR spectra of compound exhibited resonances due to aromatic systems. In the ${ }^{1} \mathrm{HNMR}$ system, it shows the presence of 50 hydrogens in the compound at 1.0-1.2 (t, $6 \mathrm{H}) ; 1.5-1.7(\mathrm{~m}, 15 \mathrm{H}) ; 2.1(\mathrm{~m}, 2 \mathrm{H}) ; 2.91-3.0(\mathrm{~m}, 2 \mathrm{H})$; 3.0 - $3.3(\mathrm{~d}, 7 \mathrm{H}) ; 3.75$ (d, 7H); 3.9-4 (d, 6H); $4.3(\mathrm{~s}, 2 \mathrm{H})$; $4.5(\mathrm{~d}, 3 \mathrm{H}) . \mathrm{C}^{13} \mathrm{NMR}$ has shown characteristic carbons in spectrum.

\section{Molecular docking studies}

Based on the in vivo study results of Aerva lanata (L) extract and fractions for Antiurolithiatic activity, it was thought to study the isolated compounds AEF 1 (Quercetin) and AEF 2.3 (Betulin) by in silico technique to support their in vivo activity. It was also thought that this study shall help to understand the mechanism of action of the enzyme and the drug in the Urolithiasis. Automated docking software was used to determine the orientation of inhibitors bound in the active site of 2 ETE enzyme of Oxalate oxidase which was found to be one of the responsible factors for stone deposition. A Lamarckian genetic algorithm method was employed for this study. The docking of legend molecules with 2 ETE of Oxalate oxidase which reportedly participate in kidney stone formation in patients, reveals that both the inhibitor compounds exhibited the binding with one or other amino acids with better regio-specificity in the active pockets, which is showed in Figure 9 and 15. The protein structure file (PDB ID: 2 ETE) taken from PDB (www.rcsb.org/pdb) was edited by removing the hetero atoms, adding C-terminal oxygen. Figure 9 and 15 also shows the in silico active pocket prediction of amino acids of protein 2 ETE involved in binding with the legends obtained from PDB Theoretically all the molecules showed very good binding energy and docking energy ranging from -3.72 to $-3.92 \mathrm{~kJ} / \mathrm{mol}$ and - 4.11 to $-4.37 \mathrm{~kJ} / \mathrm{mol}$ respectively. Among the tested compounds, docking of 2 ETE with AEF 1 and AEF
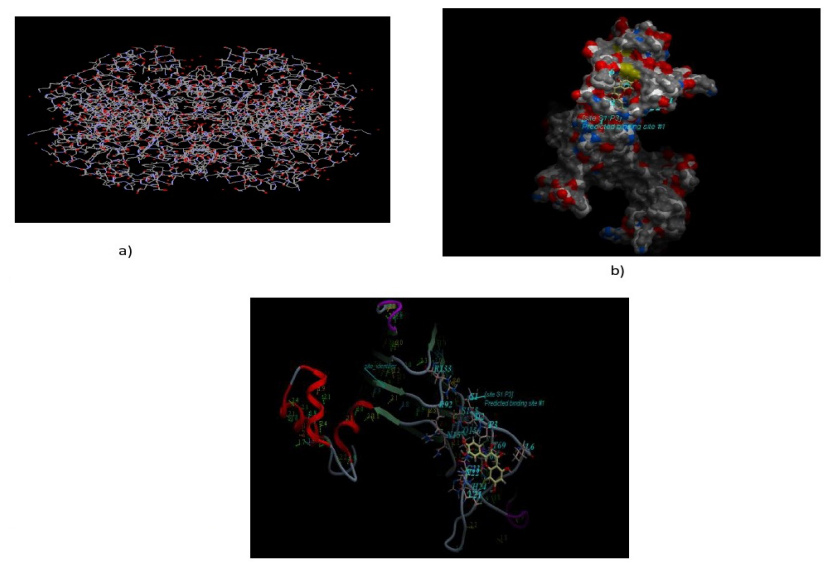

c)

Figure 15: a) 2 ETE from PDB (energy minimized ) b) Predicted binding site (2 ETE ) C) Docking of the molecule (AEF 2.3)

2.3 revealed that its docking energy and binding energy $(-4.11,-4.37$ and $-3.72,-3.92 \mathrm{~kJ} / \mathrm{mol}$, respectively ) favorable for a good inhibitor of 2 ETE. These compounds AEF 1 and AEF 2.3 need to be screened for in-vivo Antiurolithiatic activity in future. Based on the above In silico study results it can be predicted that these two compounds may be active Antiurolithiatic agents which shall be due to inhibition of enzyme 2 ETE of Oxalate oxidase.

\section{CONCLUSION}

The isolated compounds from two fractions n-butanol and ethyl acetate of Aerva lanata (L) plant extract using column chromatography were characterized by modern analytical techniques such as IR, HPTLC, NMR and LCMS as Quercetin and Betulin. These two compounds were also studied by In silico technique downloading a protein 2 ETE of Oxalate oxidase from PDB and docked with it. This has generated good docking scores which predicts good inhibitory activity on the enzyme which reportedly responsible for kidney stone formation and good candidates for better Antiurolithiatic activity.

\section{CONFLICT OF INTEREST}

Authors declare that there is no conflict of interest exists

\section{ACKNOWLEDGEMENT}

Authors thank KLE University and Principal of KLES'S College of Pharmacy, Belgaum for the present research work. Authors also thank Dr. S S Kerur, Asst Professor, KLES College of Pharmacy Hubli and Principal, KLES College of Pharmacy Hubli for the docking studies. 


\section{AQ-2 REFERENCES}

1. Nadkarni KM. Indian Materia Medica. Bombay Popular Prakashan. 1999; 1 (Issue missing?): 49-50.

2. Rajesh R. In vitro Anthelmintic Activity of Aerial Parts Aerva lanata Linn Juss. Int. J. of Pharma Sci and Drug Res. 2010; 2(4): 269-71.

3. Dinnimath BM, Jalalpure SS. Spectral Analysis of Fractions of Aerva lanata (L). Indian Journal of Natural Products 2012; 28(2): 14-8.

4. Atmani F, Slimani Y, Mimouni M, Hacht B. Prophylaxis of calcium oxalate stones by Herniaria hirsuta on experimentally induced nephrolithiasis in rats. British Journal of Urology International. 2003; 92(1): 137-40.

5. Karadi RV, Gadge NB, Alagawadi KR, Savadi RV. Effect of Moringa oleifera Lam. root-wood on ethylene glycol induced urolithiasis in rats. J Ethnopharmacol 2006; 105(1): 306-11.

6. Temidayo AR. Extraction and Isolation of Flavonoids Present in the Methanolic Extract of Leaves of Acanthospermum Hispidium Dc.Global Journal of Medicinal Plant Research. 2013; 1(1): 111-23.

7. Elvira EKB, Duric K, Kalodera Z, Sofic E. Identification and isolation of pharmacologically active triterpenes in Betuale cortex, Betula pendula Roth. Betulaceae. Bosnian J of Basic Medicals Sci. 2009; 9(1): 31-8.

8. Nickavar B, Ihasani LA. Bioactivity-Guided Separation of an a Amylase Inhibitor Flavonoid from Salvia virgata. Services. Iranian J of Pharma Res. 2013; 12(1): 57-61.
9. Joshi H, Saxena GK, Vikas Singh, Arya E, Singh RP. Phytochemical Investigation, Isolation and Characterization of Betulin from Bark of Betula Utilis. Journal of Pharmacognosy and Phytochemistry. 2013; 2(1): 145-51.

10. Yekta MM, Alavi HR. New Triterpenoids from Peucedanum ruthenicum. Iranian Journal of Pharmaceutical Sciences 2008; 4(4): 289-94.

11. Sahaa S, Subrahmanyam VS, Kodangalad C, Shastry SC. Isolation and characterization of triterpenoids and fatty acid ester of triterpenoid from leaves of Bauhinia variegata. Der Pharma Chemica. 2011; 3(4): 28-37.

12. Sawsan AR, Nahla NS, Shimaa AA, et al. Thermoanalytical Study and Purity Determination of Azelastine Hydrochloride and Emedastine Difumarate. Pharmaceut Anal Acta. 2012; 3(8): 1-4.

13. Khobragade CN, Beedkar SD, Bodade RG, Vinchurkar AS. Comparative structural modeling and docking studies of oxalate oxidase: Possible implication in enzyme supplementation therapy for Urolithiasis. Int $\mathrm{J}$ Biol Macromol. 2011; 48(3): 66-73.

14. Requena L, Bornemann S. Barley (Hordeum vulgare) oxalate oxidase is a manganese-containing enzyme. Biochem. J. 1999; 343(1): 185-90.

15. Bele U, Hajdinjak T. The Role of Oxalate in Urolithiasis. Web med Central UROLOGY 2012: 3(1): (pagination missing?)

16. Dahiya T, Pundir CS. In vivo oxalate degradation by liposome encapsulated oxalate oxidase in rat model of hyperoxaluria. Indian J Med Res. 2013; 137(1): 136-41.

AQ-1 Figure 2,3,11,14 Citation is missing in the text field

AQ-2 In Reference no 1 \& 15 issue and pagination is missing 